dr inż. Marek Sobaś

Instytut Pojazdów Szynowych „,TABOR”

\title{
Możliwości kształtowania optymalnego zarysu pojazdu tramwajowego
}

\begin{abstract}
Artykut jest poświęcony studium możliwości kształtowania optymalnego zarysu pojazdu tramwajowego $w$ oparciu o obowiazujace przepisy w zakresie skrajni kinematycznej pojazdu tramwajowego oraz skrajni budowli. W pierwszej części przedstawiono układ stopień wejściowy -peron, czynniki wplywajqce na minimalna wysokość podłogi oraz możliwości konstrukcyjne usytuowania urzqdzeń pomocniczych na dachu pojazdu tramwajowego.

Artykut powstat w ramach projektu badawczego $n r N 509$ 03531/2367, finansowanego przez Ministerstwo Nauki i Szkolnictwa Wyższego ze środków na naukę na lata 2006 $\div 2009$, pt.: „Metodyka wyznaczania kinematycznego zapotrzebowania przestrzeni oraz luzów bezpieczeństwa dla pojazdów tramwajowych, celem ustalenia optymalnego zarysu pojazdu”.
\end{abstract}

\section{Wstęp}

W związku ze zwiększającymi się wymaganiami rynkowymi w zakresie transportu miejskiego pojazd tramwajowy musi posiadać możliwie maksymalne wymiary gabarytowe, umożliwiające odpowiedni komfort jazdy pasażerów [2 $\div 5]$. Szczególną uwagę należy zwrócić w tym wypadku na:

- efektywną szerokość pojazdu tramwajowego, od której zależy między innymi układ i szerokość miejsc siedzących, szerokość korytarza przejściowego (niem. „Gangbreite”)

- zapewnienie maksymalnej rotacji podróżnych przy wsiadaniu i wysiadaniu podróżnych poprzez zastosowanie możliwie maksymalnej ilości podwójnych drzwi oraz możliwie równomiernego ich rozdziału na pełnej szerokości pojazdu tramwajowego

- efektywną wysokość pojazdu tramwajowego, od której zależy między innymi usytuowanie agregatów pomocniczych na dachu

- usytuowanie stopnia wejściowego i podłogi w stosunku do główki szyny.

Istotnym ograniczeniem projektowym dla dopuszczalnego zarysu tramwajowego jest dopuszczalny zarys odniesienia skrajni kinematycznej wg normy PN-K92008 [6] oraz PN-K-92008/Ap1 [7], po uwzględnieniu zwężeń wewnętrznych $E_{i} i$ zewnętrznych $E_{a}$. Zarys skrajni kinematycznej skrajni jest $\mathrm{z}$ kolei uwarunkowany zarysem skrajni budowli wg normy PN-K92009:1998 [8]. W przypadku niemieckich przedsiębiorstw przewozowych obowiązują $\mathrm{w}$ tym zakresie przepisy BOStrab [9]. W wyniku jazdy na torze prostym oraz łukach pojazd tramwajowy podlega przemieszczeniom geometrycznym i kinematycznym, które składają się na kinematyczne zapotrzebowanie przestrzeni ( niem. „Lichtraumbedarf”). W ponad 100letniej historii rozwoju ruchu tramwajowego przez ok.80 lat eksploatacja tramwajów zmieniła się w nieznacznym stopniu, natomiast przez ostatnie 20 lat można mówić o rewolucji $\mathrm{w}$ tym zakresie. Zmiany zostały wymuszone przede wszystkich upowszechnieniem transportu samochodowego, zwłaszcza w latach 60-tych, kiedy coraz więcej ludzi zostało posiadaczami samochodów, co spowodowało znaczne zmniejszenie ilości pasażerów komunikacji miejskiej. Zmiany, które pochodzą jednoznacznie z potrzeby racjonalizacji, miały istotny wpływ na budowę pojazdu tramwajowego. Głównym problemem, jaki powstał przy konstruowaniu nowoczesnych pojazdów tramwajowych było dopasowanie wysokości podłogi do wysokości peronów. Wskutek tego powstała nowa generacja pojazdów tramwajowych, zwanych pojazdami niskopodłogowymi (niem. „Niederflurstrassenbahnen"), które zgodnie z [1] charakteryzują się wysokością wsiadania ( niem. , Einstiegshöhe”) $<400 \mathrm{~mm}$. W przypadku tramwajów średniopodłogowych (niem. „Mittelflurstrassenbahnen”) wysokość podłogi zawiera się $\mathrm{w}$ przedziale 400 do $600 \mathrm{~mm}$, natomiast $\mathrm{w}$ przypadku tramwajów wysokopodłogowych ( niem. „Hochflurstrassenbahnen") wysokość podłogi jest większa od $600 \mathrm{~mm}$. Pierwszy tramwaj niskopodłogowy typu „20TFS2” pojawił się po raz pierwszy w Grenoble w 1987 roku, w związku z czym można już mówić o blisko dwudziestoletniej ich historii w zakresie konstruowania, produkcji i doświadczeń eksploatacyjnych. Głównym zadaniem zastosowania tramwaju niskopodłogowego w eksploatacji było przede wszystkim oprócz polepszenia wskaźnika rotacji podróżnych podczas wsiadania i wysiadania podróżnych między innymi korzystanie przez pasażerów niepełnosprawnych, pasażerów z dziećmi oraz osoby w starszym wieku ze środków komunikacji miejskiej. 


\section{Wysokość peronu tramwajowego}

Istotnym ograniczeniem skrajniowym o charakterze ciagłym dla pojazdów tramwajowych jest wysokość peronu ( niem.,, Bahnsteigshöhe"). Punktem wyjściowym do dalszych rozważań konstrukcyjnych jest wysokość stopnia wejściowego ( niem.,, Türaustrittshöhe” lub „Einstiegshöhe”), która wynosi w większości eksploatowanych pojazdów tramwajowych $290 \div 300 \mathrm{~mm}$. Zastosowanie tramwajów niskopodłogowych powoduje rezygnację z pośredniego stopnia wejściowego (" niem. Trittstufe"), co powoduje znaczne efekty przyspieszające rotację podróżnych, widoczne dla przykładowych tramwajów niskopodłogowych dla Grenoble (Francja) oraz Genewy ( Szwajcaria). W wyniku poprawy warunków wsiadania i wysiadania należy liczyć się, że przy drzwiach podwójnych ( niem. „, Doppeltür”) ilość pasażerów będzie dochodziła nawet do 40 .

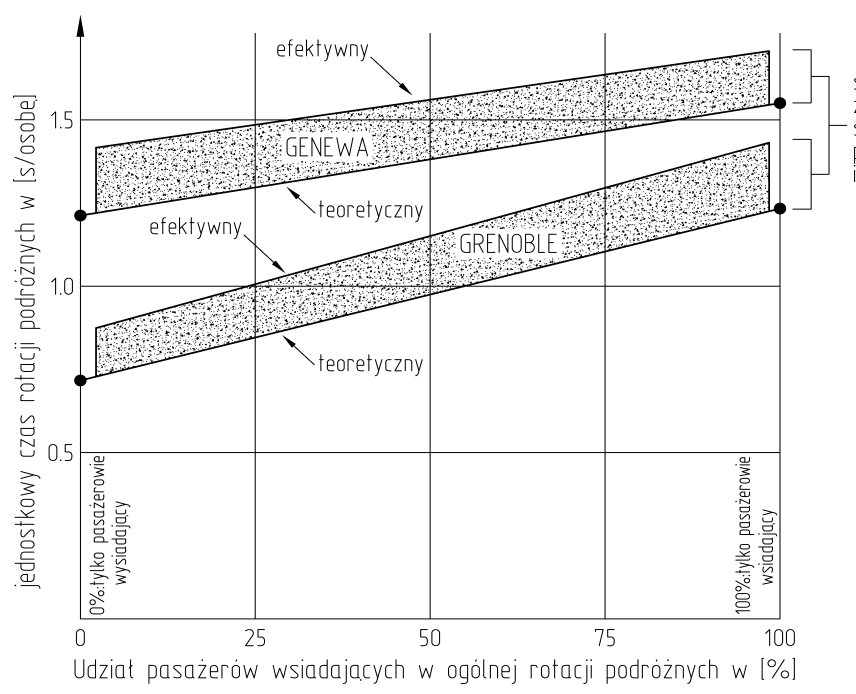

Rys.1. Zwiększenie efektywności jednostkowego wskaźnika rotacji pasażerów wsiadających i wysiadających (niem. „Fahrgastwechselzeit") na przykładzie tramwaju niskopodłogowego dla Grenoble w stosunku do tramwaju dla Genewy

Kolejnym przykładem polepszenia warunków wsiadania i wysiadania dla pasażerów jest tramwaj niskopodłogowy dla Kasell ( niem.,, Kasseler Niederflurfahrzeug"), co jest przedstawione na rys.2.

Jak widać z przykładu pokazanego na rys.2, warunkiem zwiększenia komfortu przy wsiadaniu oraz wysiadaniu przez podróżnych jest nie tylko zmniejszenie wysokości podłogi i stopnia wejściowego pojazdu tramwajowego, ale również odpowiednie dopasowanie wysokości peronu. W stanie nowym pokazanym na rys.2, różnica wysokości pomiędzy stopniem wejściowym oraz peronu wynosi $70 \div 110 \mathrm{~mm}$. Warunki wsiadania i wysiadania dla pasażerów tramwaju niskopodłogowego typu 6NGTW w stanie nowym oraz najbardziej niekorzystnym z punktu widzenia statycznego ugięcia i maksymalnego zużycia szyn oraz powierzchni tocznej kół w przypadku peronu o wysokości 180 $\mathrm{mm}$ przedstawiono na rys.3.

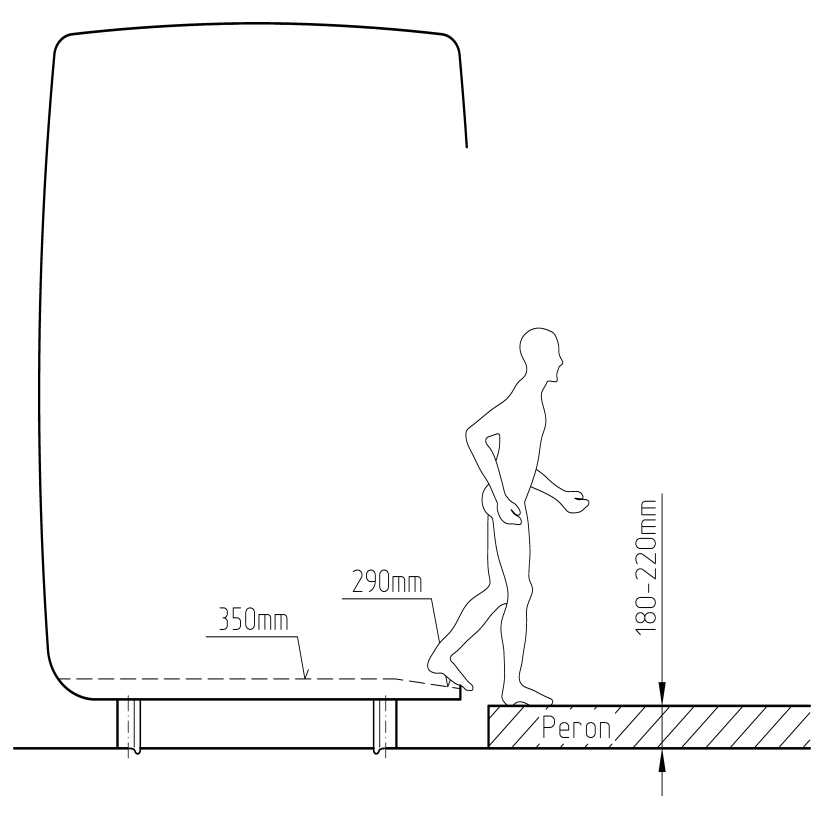

Rys.2. Warunki wsiadania i wysiadania dla podróżnych w przypadku tramwaju niskopodłogowego typu 6NGTW dla spowodowanego przez
pasażerów wsiadajacych wysiadajacych jednocześnie

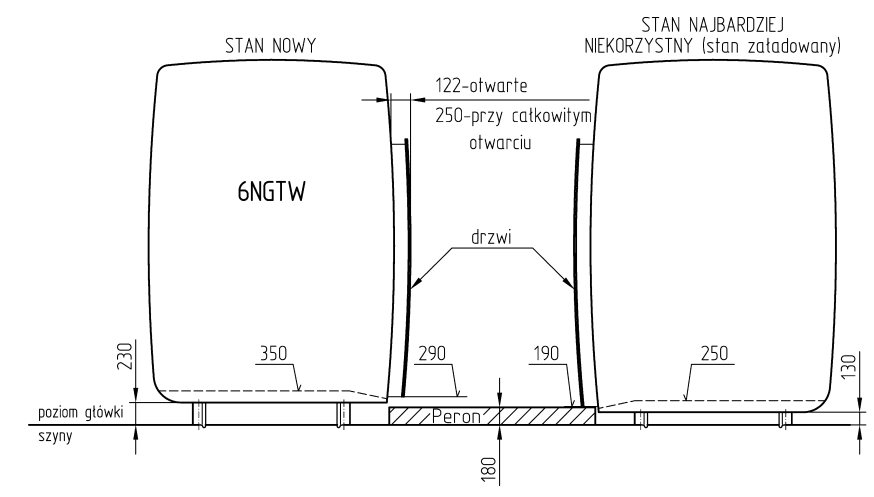

Rys.3. Usytuowanie tramwaju niskopodłogowego typu 6NGTW na tle peronu o wysokości $180 \mathrm{~mm}$

Czynniki wpływające na usytuowanie stopnia wejściowego sprowadzają się do:

- połowy zużycia wieńca koła na powierzchni tocznej (niem.,,1/2 Radreifenverschleiss”): 20 $\mathrm{mm}$

- ugięcia usprężynowania w stanie statycznym, kołysanie pudła ( niem. , Durchfederung, Wanken"): $65 \mathrm{~mm}$

- zużycia szyn ( niem. „Schienenabnutzung”): 15 $\mathrm{mm}$

- swobodnej przestrzeni ( niem. „Freiraum”): 10 $\mathrm{mm}$, co daje łączne zmniejszenie wysokości podłogi ( stopnia wejściowego) wynoszące 110 mm i wynikającą $z$ tego wysokość peronu wynosząca $290-110=180 \mathrm{~mm}$. 
Jeśli ugięcie i kołysanie udałoby się zmniejszyć z 65 $\mathrm{mm}$ do $50 \mathrm{~mm}$ oraz zużycie szyn do $10 \mathrm{~mm}$ wówczas zmniejszenie wysokości podłogi ( stopnia wejściowego) wynosiłoby $90 \mathrm{~mm}$ i wynikałaby z tego wysokość peronu wynosząca $290-90=200 \mathrm{~mm}$. Powyższe obliczenia uzasadniają przyjętą wysokość dla peronów w Kassel wynoszącą $180 \div 200 \mathrm{~mm}$. Zużycie szyn w kierunku pionowym jest przyjęte na podstawie wymogu regularnych kontroli przeprowadzonych przez przedstawicieli infrastruktury. Zgodnie z przepisami krajowymi dla miejskich przedsiębiorstw przewozowych dopuszczalne zużycie szyn w kierunku pionowym wynosi odpowiednio:

-dla szyn rowkowych $\mathrm{P} \leq 18 \mathrm{~mm}$

-dla szyn kolejowych:

- o dopuszczalnym ciężarze jednostkowym do $422 \mathrm{~N} / \mathrm{m}: \mathrm{P} \leq 12 \mathrm{~mm}$

- o dopuszczalnej ciężarze jednostkowym powyżej $422 \mathrm{~N} / \mathrm{m}$ : P $\leq 15 \mathrm{~mm}$ [11].

Zgodnie z niemieckimi przepisami BOStrab [10] pionowe zużycie szyn pomiędzy dwoma okresami naprawczymi, w których dokonuje się podbijania podkładów przyjmuje się nawet na poziomie $5 \mathrm{~mm}$ ( niem. "vertikaler Schienenverschleiss zwischen zwei Stopfintervallen"). W związku z powyższymi wymogami sformułowanymi dla polskich oraz niemieckich przedsiębiorstw komunikacyjnych ograniczenie zużycia szyn w kierunku pionowym do $10 \mathrm{~mm}$ wydaje się być realne.

\section{Czynniki wpływające na usytuowanie podłogi tramwaju nisko-podłogowego względem pero- nu}

Zużycie wieńca koła i szyny jest we wzajemnej zależności i odbywa się $\mathrm{w}$ wyniku procesów niszczących zachodzących na wzajemnie stykających się powierzchniach. Wielkości, które wpływają w sposób znaczący na zużycie i których procentowy udział w zużyciu kół odbywa się wg następującej reguły dla danej sieci toru:

- w $10 \%$ jest zależne od luzu zestawu kołowego w torze

- w $40 \%$ jest zależne od rodzaju prowadzenia zestawu kołowego w torze

- w 50\% jest zależne od własności materiałowych wieńca koła.

Podane wartości procentowe mogą się zmienić w zależności od okoliczności, jednakże podają one zasadnicze wytyczne do poprawy sytuacji w zakresie zużycia.

Zasadniczo zużycie kół pojazdów tramwajowych można zmniejszyć poprzez stworzenie lepszych warunków ruchu tocznego oraz poprzez lepsze warunki ustawiania się zestawów kołowych w łuku toru.

Następujące środki konstrukcyjne przyczyniają się do mniejszego zużycia kół zestawów kołowych:
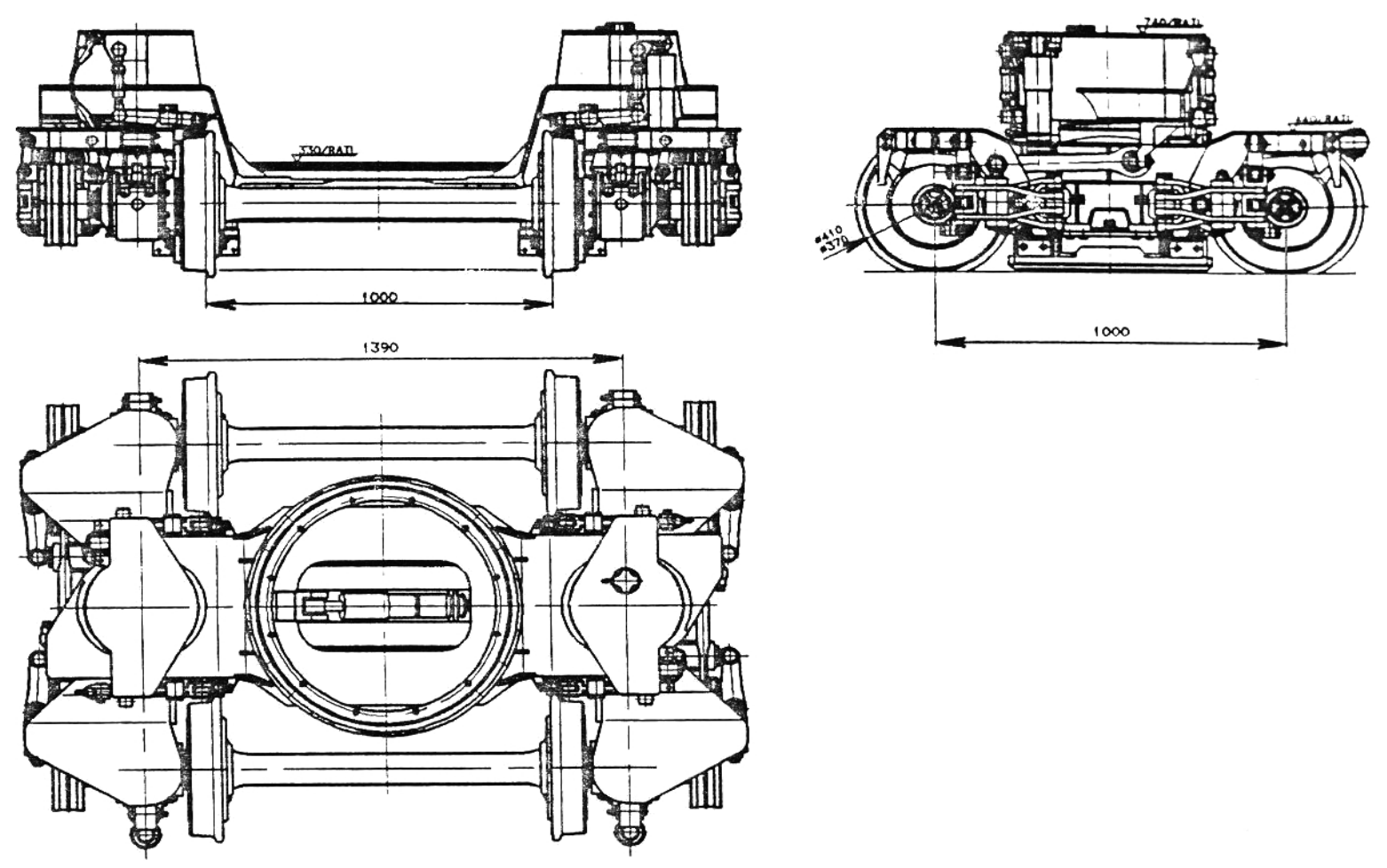

Rys.4. Układ biegowy toczny dla tramwaju niskopodłogowego w Bernie 
- krótka baza, stąd mały kąt nabiegania pomiędzy kołem i szyną podczas jazdy na łuku toru

- elastyczne prowadzenie wzdłużne zestawów kołowych, przez co mogą się ustawiać w łuku toru sposób częściowo radialny, poprzez " samonastawianie się"

- elastyczne prowadzenie poprzeczne zestawów kołowych, z czego wynika nabieganie na tuk ze zmniejszonym uderzeniem podczas nabiegania

- zredukowana masa nieusprężynowana dzięki zastosowaniu techniki kół o małych średnicach

- zredukowana masa własna układu biegowego ( niem. „Niederflurlaufwerk”) w wyniku zastosowania kompaktowej, zwartej budowy ( niem. , kompakte Bauweise”)

- zmniejszony moment obrotowy wózka poprzez zastosowanie łożyska obrotowego

( niem „, Kugeldrehkranz”) poprzez zmniejszenie sił prowadzących.

Z powyższego wynika, że zastosowanie wózka o klasycznej budowie dla tramwajów niskopodłogowych jest niemożliwe.

Potwierdzenie skuteczności zastosowanych ww. środków konstrukcyjnych dostarczyły badania eksploatacyjne ( podczas komercyjnej eksploatacji) przeprowadzone w Bernie w 1988 roku. Zużycie koła po przebiegu $83100 \mathrm{~km}$ układu biegowego dla tramwajów niskopodłogowych ( rys.4) jest przedstawione na rys.5.

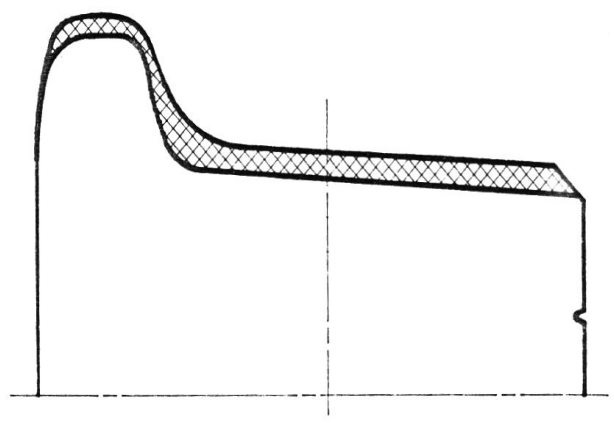

Rys.5. Zużycie zarysu zewnętrznego wieńca koła po $83100 \mathrm{~km}$ dla wózka tocznego niskopodłogowego ( niem. „Niederflurdrehgestell”)

Zużycie koła o średnicy w stanie nowym $\varnothing 410 \mathrm{~mm}$ (przystosowane do maksymalnego pionowego obciążenia statycznego na szynę wynoszącego $35 \mathrm{kN}$ ) po przebiegu wynoszącym $83100 \mathrm{~km}$ wynosiło ok. $4 \mathrm{~mm}$ na promieniu w płaszczyźnie okręgu tocznego. Różnica średnic obydwu kół zestawu kołowego wynosiła mniej niż $0,3 \mathrm{~mm}$. Na koła została zastosowana stal stopowa o wytrzymałości na rozciąganie $\mathrm{R}_{\mathrm{m}}=880 \div 980$ MPa z maksymalną zawartością węgla $0,60 \%$. Na uwagę zasługuje $\mathrm{w}$ miarę równomierne zużycie zarysu zewnętrznego wieńca koła. Uzyskane pozytywne wyniki badań można przenieść również dla kół o normalnej średnicy tocznej $\varnothing 660 \mathrm{~mm}$. Zmniejszonemu zużyciu kół zestawów kołowych w wyniku zastosowanych środków konstrukcyjnych towarzyszą bardzo korzystne efekty uboczne, do których zalicza się między innymi polepszenie komfortu jazdy, zmniejszenie emisji hałasu do otoczenia podczas jazdy i mały opór toczenia w łukach toru. Doświadczenia eksploatacyjne z małymi kołami $\varnothing 410 / 370 \mathrm{~mm}$, przeprowadzone w 1988 roku zostały wykorzystane w nowej generacji tramwajów typu NGT 8D użytkowanych przez BSVAG ( Braunschweig)-rok budowy 2007, typu ST14 użytkowanych przez HEAG ( Darmstadt)-rok budowy 2007 oraz typu NGT8G użytkowanych przez GVB (Gera)-rok budowy 2006/2007. Ww. tramwaje niskopodłogowe posiadają wózki toczne $\mathrm{z}$ małymi kołami o średnicy Ø $410 / 370 \mathrm{~mm}$ ( stan nowy/stan zużyty) oraz wózki napędne z kołami o średnicy $590 / 510 \mathrm{~mm}$. Dzięki zastosowaniu wózków tocznych z małymi średnicami tocznymi kół udało się osiagnąć $67 \%$ udział obniżonej podłogi ( niem. „Niederfluranteil").Istotnym czynnikiem ograniczającym zastosowanie kół o małych średnicach jest oprócz ograniczenia dopuszczalnego nacisku pionowego ( statycznego oraz dynamicznego) jest dolne ograniczenie zarysu skrajni kinematycznej, które w przypadku polskich przepisów PN-K-92008:1998 [7] oraz PN-K-92008/Ap1:1998 [8] wynosi $60 \mathrm{~mm}$ od główki szyny, natomiast w przepisach Zachodniej Europy $50 \mathrm{~mm}$ [2].

\section{Możliwości konstrukcyjne w zakresie usytuowa- nia urządzeń pomocniczych na dachu tram- waju}

Jedną z ważniejszych tendencji rozwojowych w tramwajach niskopodłogowych jest zastosowanie na ich dachu urządzeń o budowie modułowej ( niem.,, Gerätemodule"), które w celu ułatwienia montażu i demontażu podczas prac remontowych i kontrolnych są wyposażone ucha ułatwiające zaczepianie przez urządzenia dźwigowe ( niem. „Kranösen” lub „, Befestigungsösen“). Przykłady rozmieszczenia urządzeń pomocniczych o budowie modułowej na dachu tramwaju z obniżoną podłogą typu VÖV są przedstawione na rys.6, 7 i 8 . Tramwaj został opracowany na zlecenie niemieckiego Ministerstwa Badań i Rozwoju (niem.,, Bundesministerium für Forschung und Technologie") oraz Ministerstwa Komunikacji ( niem. „Bundesministerium für Verkehr") przez konsorcjum pod przewodnictwem Rheinische Bahngesellschaft GmbH. 


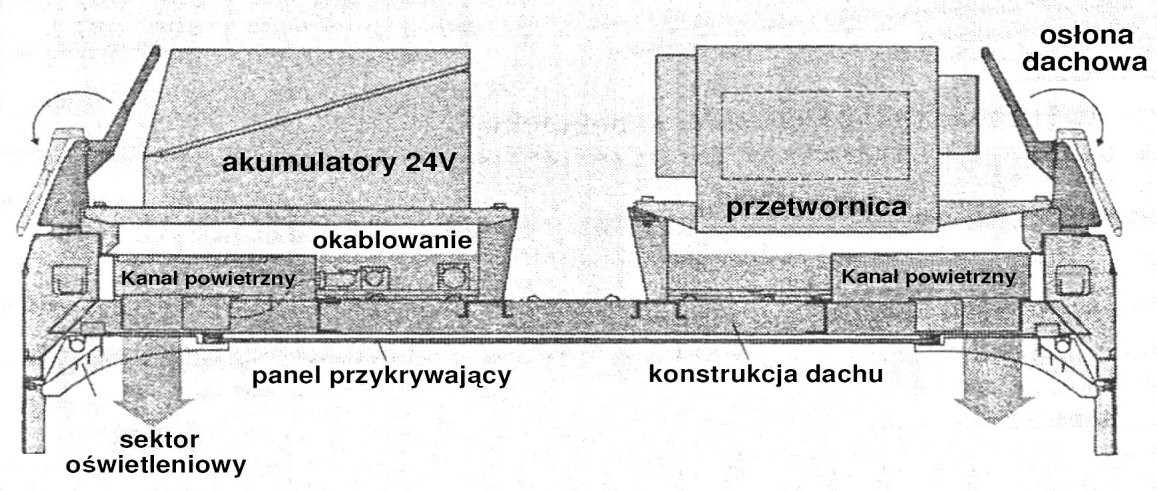

Rys.6. Przekrój dachu tramwaju niskopodłogowego typu VÖV wyposażonego w urządzenia pomocnicze o budowie modułowej

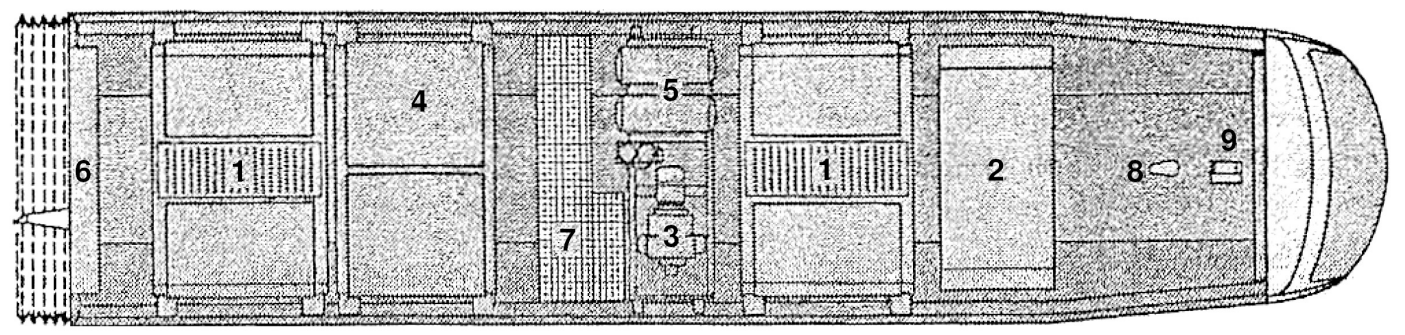
1.Przetwornica
2.Ogrzewanie
6.Obudowa przegubu
3.Sprężarka
7.Ruszt
4.Skrzynia na urządzenia
8.Antena
5.Zbiornik powietrza
9.Urządzenie IRIS

Rys. 7. Rozmieszczenie urządzeń pomocniczych na części „A” przegubowego tramwaju niskopodłogowego typu VÖV

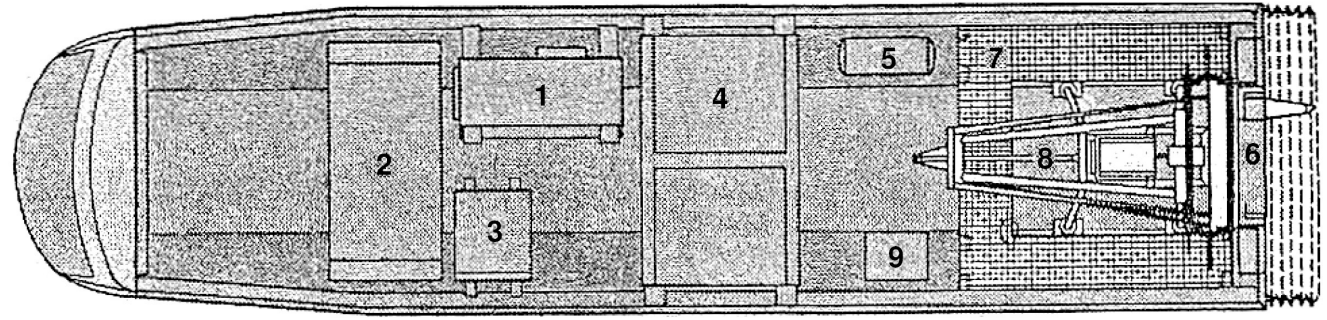

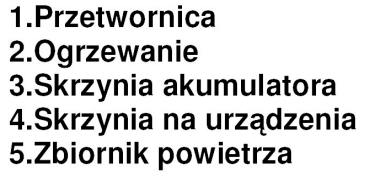

1.Przetwornica

3.Skrzynia akumulatora

4.Skrzynia na urządzer
5.Zbiornik powietrza
6.Obudowa przegubu

7.Ruszt

8.Odbierak prądu

9.Napęd odbieraka prądu

Rys.8. Rozmieszczenie urządzeń pomocniczych na części „B” przegubowego tramwaju niskopodłogowego typu VÖV

Rozmieszczenie urządzeń pomocniczych odbywało się przy uwzględnieniu warunków:

- modułowa budowa poszczególnych urządzeń

- równomierne rozmieszczenie mas względnie rozkład nacisków pionowych kół

- funkcjonalne rozmieszczenie modułów przy minimalnym orurowaniu i okablowaniu.
- ze względu na narażenie konstrukcji na warunki atmosferyczne, urządzenia pomocnicze muszą wykazywać wymagane warunki szczelności i zabezpieczenia antykorozyjnego. 
Urządzenia modułowe są kompletnie okablowane i podlegają odbiorowi przez każdego z producentów. Kolejną cechą lokalizacji urządzeń modułowych jest montaż na sztywno lub usprężynowane za pomocą elementów gumowo-metalowych thumiących drgania i uderzenia o charakterze udarowym w zależności od ich cech konstrukcyjnych.

Urządzenia umieszczone na dachu części A ( $\mathrm{z}$ dwoma wózkami napędnymi) posiadają masę całkowitą ok.1600 kg, natomiast cześć B ( $\mathrm{z}$ jednym wózkiem tocznym) $1200 \mathrm{~kg}$. Osłony dachowe ( niem., Dachblende") po poluzowaniu kilku połączeń zatrzaskowych mogą być odchylone, przez co powstaje możliwość korzystnej dostępności do urządzeń, celem wykonania prac konserwacyjnych i naprawczych ( rys.9).

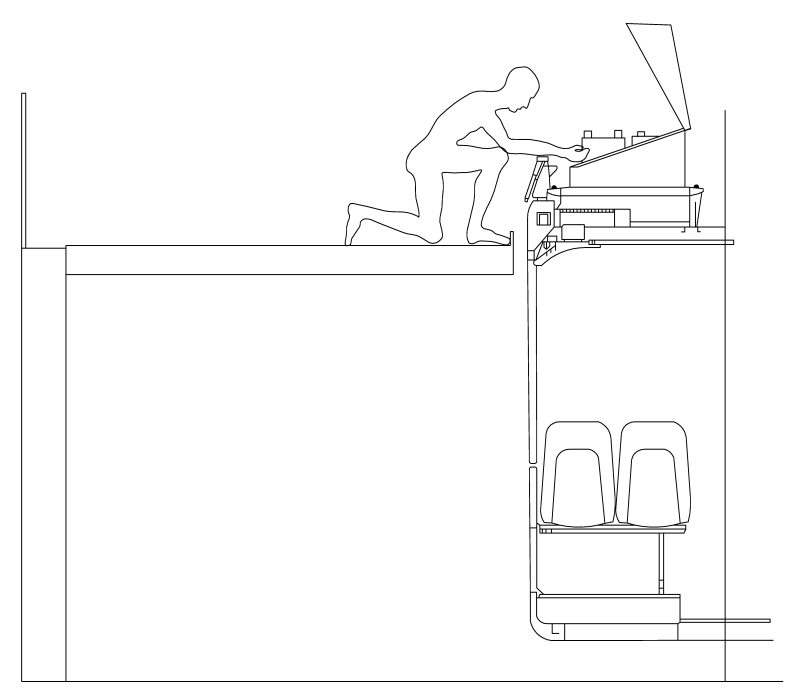

Rys. 9. Dostępność urządzeń o budowie modułowej rozmieszczonych na dachu pojazdu tramwajowego typu VÖV przy pracach konserwacyjnych i naprawczych przy użyciu pomostu roboczego (niem.,, Arbeitsbühne”)

Osłony dachowe są wykonane $\mathrm{z}$ ujednoliconych, znormalizowanych części i po zluzowaniu kilku połączeń śrubowych są łatwe do zdemontowania oraz spełniają warunek zamienności. Modułową zabudowę urządzeń pomocniczych umożliwia specjalna konstrukcja dachu, przedstawiona na rys. 10 .
Pomiędzy obydwoma zewnętrznymi podłużnicami dachu (1) są przykręcone poprzecznice (2) w praktycznie równej odległości. Wzdłuż przebiegają jeszcze pośrednie elementy nośne (3) i w celu lepszego podparcia dachu trzy dalsze małe profile podpierające (4). Płaszcz dachu został ukształtowany lekko pod górę, aby uniknąc koncentracji wody. Konstrukcja dachu umożliwia swobodne przechodzenie dla personelu obsługującego, jak również bardzo dobre dojście do stref o szczególnym znaczeniu jak np. miejsca zainstalowania odbieraka prądu.

\section{Literatura}

[1] Hondius H.: Entwicklung der Niederflurstrassenund Stadtbahnen. Stadtverkehr Nr.12/2007

[2] Müller A.: Niederflur-Stadtbahnwagen. Eine neue Fahrzeuggeneration. Vorträge der ETG Fachtagung vom 13 bis 14 März 1990 Kassel. ETG-Fachbericht Nr.31.

[3] Sobaś M.: Skrajnia kinematyczna i budowli pojazdów tramwajowych. Pojazdy Szynowe Nr 3/2007

[4] Sobaś M.: Analiza przemieszczeń geometrycznych i kinematycznych krajowych pojazdów tramwajowych na torze prostym oraz na tuku o minimalnym promieniu. Pojazdy Szynowe Nr 4/2007

[5] Sobaś M.: Luzy bezpieczeństwa między skrajniq kinematycznq i skrajniq budowli dla pojazdów tramwajowych (1). Pojazdy Szynowe Nr 1/2008.

[6] Sobaś M.: Luzy bezpieczeństwa między skrajniq kinematycznq i skrajniq budowli dla pojazdów tramwajowych (2). Pojazdy Szynowe Nr 1/2008

[7] NormaPN-K-92008:1998: Komunikacja miejska. Skrajnia kinematyczna wagonów tramwajowych.

[8] Norma PN-K-92008/Ap1:1998: Komunikacja miejska. Skrajnia kinematyczna wagonów tramwajowych.

[9] Norma PN-K-92009:1998: Komunikacja miejska. Skrajnia budowli. Wymagania.

[10] Tymczasowe wytyczne dla określenia zapotrzebowania przestrzeni dla kolei miejskich wg zarzadzenia dotyczqcego budowy i eksploatacji tramwajów (niem. ,Vorläufige Richtlinien für die Bemessung des lichten Raumes nach der Verordnung über den Bau und Betrieb der Straßenbahnen( BOStrab-LichtraumRichtlinien))".12. 1996.

[11] Wytyczne techniczne projektowania budowy i utrzymania torów tramwajowych. Ministerstwo Administracji, Gospodarki Terenowej i Ochrony Środowiska. Departament Komunikacji Miejskiej i Dróg. Warszawa 1983.

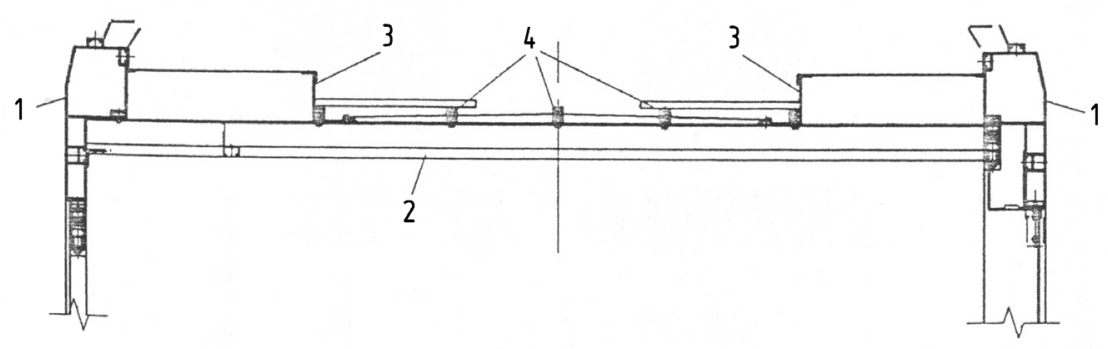

1 - ostojnice dachowe

2 - poprzecznice

3 - poprzecznice pośrednie

4 - profile podpierajace
Rys.10. Konstrukcja dachu tramwaju z obniżoną podłogą typu VÖV 